\title{
Design and Application of E-Learning Environment Layered Structure Model in Colleges and Universities
}

\section{Fang Fang}

Shaanxi University of Science \& Technology, Xi'an 710021, Shaanxi Province, China.

E-mail: 464219350@qq.com.

\begin{abstract}
There are problems such as unclear labor division and insufficient contact between departments in the e-learning education environment in higher education. Each of colleges or universities needs to design its own model and apply it to the education and teaching environment based on the unique structure, organization, management system and other conditions to improve the management efficiency of learning, education and teaching, which improves the level of management and gives full play to its role. This article briefly discusses the design and application of e-learning environment layered structure model in colleges and universities.
\end{abstract}

Keywords: Education; E-learning; Teaching; Layered Structure Model

Introduction

This article analyzes problems existing in the e-learning environment in colleges and universities, and studies the layered structure model for the design of e-learning education and teaching. Besides, this article also describes the basic application methods for the model. Finally, this article briefly explains the application practice of e-learning environment layered structure model.[1].

\section{Problems existing in the e-learning education in colleges and universities}

Difficulties for teaching management is gradually increasing due to the change of the existing teaching application mode and personnel training mode in various colleges and universities. Education management shows the features of openness, diversity and dynamics and highly centralizes the teaching management mechanism. Most colleges and universities adopt the teaching mechanism of separate management of schools and colleges, the education and teaching resources are therefore limited, and most of the management tasks are concentrated in school-level management departments. As for the management process, each university focuses on working tasks, and thus form a fixed management plan [2]. However, there are many problems in the actual management process, such as the lack of clear working procedures, the lack of strengthening the links between departments, the lack of a sound feedback mechanism and other series of problems, resulting in management omissions, shirking responsibilities, unclear work duty, duplication of labor and other phenomena, which is seriously affecting the efficiency of management. For management approaches, colleges and universities are usually equipped with educational and teaching resources through computer network organization, and the information management method is adopted. In the process of information construction, various management departments often set up application systems to provide services for their own businesses according to their own situations and development requirements. Moreover, the information between different departments cannot be shared because the technical standards are not the same, which leads to the application can only be concentrated in some local parts and fails to expand to the overall situation.

Copyright (C) 2020 Fang Fang

doi: $10.18282 /$ le.v9i6.1353

This is an open-access article distributed under the terms of the Creative Commons Attribution Non-Commercial License

(http://creativecommons.org/licenses/by-nc/4.0/), which permits unrestricted non-commercial use, distribution, and reproduction in any medium, provided the original work is properly cited. 


\section{Design of layered structure model for e-learning in higher education}

In order to solve the problems existing in the construction of e-learning environment, we should think about the establishment of the e-learning layered structure model with scientific vision and systematic thought. Management, organization, technology and other issues should be considered together. According to relevant practical researches, an information engineering college has put forward a four-level model for the construction. The model is divided into levels including basic environment support, application support, application system and user level. The main purpose for setting up the basic environment support level is to build a safe, stable, fast and efficient network as well as its server hosting center, open information service platform and other basic hardware facilities for the whole campus. The major purpose for building the application support level is to build a data information center including teachers, students and other basic information centers for the whole, which can provide a data exchange center system after user authentication. The major purpose of setting up the application system level is to build an application system covering teaching and researches, information management, manpower management, enrollment, employment, books and information services and logistics services for the whole campus. The main purpose for building the user level is to adopt business process reengineering (BPR), build a demand-oriented business organization that optimizes the process, and innovate and design the process of business management.

The four levels are independent of each other and each of the levels has a clear responsibility, regardless of the construction succession. The four levels work and cooperation based on the standards of the construction system. At the same time, the construction of e-learning environment has effectively improved the efficiency. The construction of the four-level model has the following advantages. Firstly, it can clearly divide the scope of each department's construction, subsystem interface, management and responsibility at this level. The second is to unify the data standards, which can realize the collection, classification, sharing and induction of all kinds of data information. Finally, the established education and teaching information protection system have the features of integrity, hierarchy, stability and expandability.

\section{The basic application method of the construction of e-learning environment layered structure model in higher education}

Under the four-level model, it is necessary to set up a leading group for e-learning education for campus, implement the construction work at all levels effectively and establish the main body of responsibility, unify the standards of basic information data of the whole school, and directly supervise its management technical standards by the leading group for informatization to ensure the smooth development under the right direction. The following content will introduce the construction process at all levels.[5]

\subsection{Construction of security, stability, fast and efficient application network in campus}

First of all, a safe, stable, fast and efficient application network should be built for the campus in the first layer. For example, the campus should build network optical fibers for multiple campuses, an exclusive internal virtual network for financial management, an exclusive internal virtual network for educational administration, and so on. The school will build a server hosting center to ensure issues such as fire safety, lightning protection safety, power supply safety and network safety brought after the continuous 24-hour operation of the server. It is still necessary to provide technical support such as 24-hour monitoring of operation and maintenance to save people, goods and financial resources. The bottleneck problem of students using the information management system can be solved after establishing an open information service platform.

\subsection{Building data information center}

Secondly, a database based on designed for the campus should be built for second layer, including the basic data information center for teachers and students, as well as the data buffer and interaction center for collection, collation, induction and data provision. Subsystems should use the basic data information center as a standard and build a unified user authentication platform on campus according to the data buffered and data exchanged in by the exchange center to integrate and share data in the existing and the newly established system [6]. 


\subsection{The construction of management application system}

The third layer should build a network comprehensive education and teaching management platform, educational administration, administration, student management, enrollment management, employment management, library service management, homepage information management, asset management, postal management, logistics management and other business management application systems within the campus network. In the process of construction, a systematic analysis method is adopted to describe and analyze the current business processes according to the capabilities of information technology to find the transmission and control relationships of business processes, and to construct a new business process framework. A targeted construction system according to the new business processes not only carry out independent development, but also introduce advanced concepts.

\subsection{Establishment of a management unit to ensure its information construction}

The main body to be built on the fourth layer is management unit. Each management unit can create a new business management mode or improve the previous mode according to the business process on the third layer. According to the re-division of personnel and the re-adjustment of institutions, it realizes the organizational reengineering and ensures the information-based organizational construction.[7]

The ultimate goal of building the e-learning environment is to improve working process of education management, not only for the design of information management system, but also for a small part of e-learning construction. According to the layered structure model, the construction has achieved the overall process of improvement and perfection, and the construction will also continue. Only through continuous construction can it be applied and accepted in the practical management process.

\section{The application and practice of e-learning environment layered structure model in in colleges and universities}

Each university adopts an information construction method based on a four-level model to build an efficient network across campus. An university may set up a server hosting center to host 300 servers throughout the campus. In buildings such as teaching buildings, libraries and laboratories, an open platform composed of more than 80 computers is distributed, which not only meets the needs of students in selecting courses, but also meets the needs of them in querying materials and printing them. A campus-oriented basic data center has been established. Through cooperation with thirdparty enterprises, a data buffer, data interaction center and authentication platform have been built. All businesses are managed by schools. More than ten educational and teaching management platforms such as educational administration management, student management, enrollment management, employment management and library service management have been developed and purchased. These systems need to be identified by the information leading management team. Universities need to build up service consciousness of each department, reorganize the business process in an all-round way according to the reorganization, and reengineer more than one hundred processes. In this method, it basically realizes the change of business from "functional type" to "process type", "layered type" to "flat type", and therefore further improves the work efficiency. The system of higher education in the management process has basically achieved the integration of information system and educational management concepts by covering the key points of campus management with a few cost, and has improved the function of overall modern educational management. The new work flow presents the management concepts of modern education such as "all-round management", "service quality" and "sharing information". It attaches importance to the process and pays attention to human factors, and thus promotes the innovation and development of overall campus education effectively.

\section{Conclusion}

There are four layers of the information construction in colleges and universities. Each of the layers has different functions, which can simplify complex problems and reduce the difficulties effectively in the information process. Layered construction is to reorganize the management process through the innovative construction idea of layered structure model, bringing innovation to the management work. Therefore, the layered structure model is helpful to the 
construction and brings a new choice for the e-learning environment.

Acknowledgements

This article was supported by the 2019 Higher Education Scientific Research Project under Shannxi Association of Higher Education, which is Researches on E-Learning Environment in Colleges and Universities - On the basis of System Model (No. XGH19112). This article was also supported by the 2019 Teaching Reform Research Project under Shaanxi University of Science \& Technology, which is Researches on the Construction of Hybrid Learning Model under the Background of "Internet+"-Based on the Intelligent Teaching Tool "Rain Classroom" (No. 19Y034).

\section{References}

1. Wang A. Education for technological change: study on the construction model of information environment in yunnan border ethnic schools (in Chines) [Master thesis]. Chongqing: Southwest University; 2014.

2. Pu C. Research on evaluation of normal school students' information teaching ability based on game theory combination empowerment (in Chinese) [Master thesis]. Chongqing: Chongqing Normal University; 2019.

3. Liu Y, Li L, Xie B, et al. Research on the development of educational technology in the process of informatization project report (in Chinese). Educational Technology: Research on New Development in the Information Age (in Chinese) 2007.

4. Wu S, Zhang W, Min W, et al. Research on information construction of higher education based on hierarchical model (in Chinese). Chinese University Science \& Technology, 2014; (04): 79-80.

5. Zhao H, Liu G, Ma M. A review of researches on knowledge construction under the background of information in China. Journal of Distance Education 2014; 32(05): 47-57. doi: 10.3969/j.issn.1672-0008.2014.05.006.

6. Zhao W. Research on service-oriented digital campus model of higher education (in Chinese). Journal of Yangtze University (Natural Science Edition), 2009. doi: 10.3969/j.issn.1673-1409-C.2008.03.069.

7. Gao D, Shen X, Ning Y, et al. Design and application of hierarchical model of information teaching environment in colleges and universities (in Chinese). Modern Education Technology 2011; 21(02): 52-56. 